\title{
Participants' Perceptions Of The Impact Of The Wonder Of Reading Programme
}

\author{
Marilyn Nottingham Robertson \\ Project Manager/Co-ordinating Field Librarian \\ Library and Information Services \\ Los Angeles Unified School District \\ U.S.A.
}

\begin{abstract}
By spring, 2003, The Wonder of Reading, a non-profit organisation, had partnered with 100 Los Angeles area elementary schools to implement their 3R Programme: Renovate, Restock, and Read. The study examined the impact of The Wonder of Reading Programme in selected schools as perceived by administrators, teachers, library staff, and parent. Further, the study examined variations in perception by role and by school characteristics. Participants perceived that the project led to a cascade of changes in practices, policies, and attitudes impacting student access to print, engagement in reading, and student achievement.
\end{abstract}

\section{Background and Purpose}

\section{The Wonder of Reading}

The Wonder of Reading is a nonprofit organisation of people whose stated purpose is to "inspire in children the love of reading." Since 1995, the organisation has partnered with schools in the Los Angeles Unified School District to provide matching funds to implement a 3R Program-Renovate, Restock and Read. The organisation provides funding to double the size of elementary school libraries to approximately 1700 square feet; installs new shelving, story stairs, carpeting and other facility enhancements; provides $\$ 10,000$ for the purchase of new books; and works with the school to train and place adult volunteer reading partners to work one-on-one with students. By spring, 2003, the organisation had renovated 100 school libraries.

\section{Purpose}

The purpose of the study was to assess the impact of The Wonder of Reading programme. In a larger sense, it was to investigate the impact of improving elementary libraries in urban schools.

\section{Research Questions}

The research investigated the impact of The Wonder of Reading programme in selected schools in Los Angeles as perceived by administrators, teachers, library staff, and parents. The study also compared variations in pereeption by role and by school characteristics. 
The theoretical framework for the study centred on research related to print access, time spent reading, motivation, and school library research showing the positive role of school libraries in improving student achievement.

There is a growing body of evidence that children of poverty have markedly limited access to print of all kinds in relation to their more affluent peers (Duke, 2000; Guice, Allington, Johnston, Baker, and Michelson, 1996; McQuillan, LeMoine, Brandin, and O'Brian, 1997; Neuman and Celano, 2001; Smith, Constantino, and Krashen, 1997). On the other hand, there is evidence that where students are flooded with age-appropriate, appealing books and given opportunities to engage meaningfully with them at school and at home, positive changes can be seen in students' concepts of and engagement with print, listening comprehension, and motivation to read (Elley and Mangubhai, 1983; Krashen, 1993; Koskinen et al, 2000; Neuman, 1999).

Time spent reading and engagement in reading is an important predictor of reading success (Anderson, Wilson, and Fielding, 1988; Cullinan, 3000; Greaney and Hegarty, 1987; Kirsch et al, 2002; Krashen, 1993; McQuillan, 1998; Taylor, Frye, and Maruyama, 1990, Morrow and Weinstein, 1986; Romatowski and Trepanier-Street, 1993).

Reading motivation has been the focus of inquiry by Gambrell (1996), Worthy (1996), and Turner (1995). Gambrell found that access to books in the classroom, opportunities for self-selection, familiarity with books, and conversations about reading, particularly with adults who were engaged readers, supported the development of intrinsic motivation. She concluded that motivation and engagement with print are enhanced where there is planning time for staff, reading choice for students, opportunities to read for enjoyment, and funding for increased access to high-interest material. Krashen (1993) concurred, noting that "light reading is a hook that may be the way that nearly all of us learned to become avid readers" (p. 47).

Increasingly, studies suggest that school library programmes have a positive impact on student achievement (Baughman, 2000; Gaver, 1963; Lance, Hamilton-Pennell and Rodney, 1999; Lance, Rodney, and Hamilton-Pennell, 2000; Lance, Rodney and HamiltonPennell, 2002; Lance, Welborn, and Hamilton-Pennell, 1993; Smith, 2001). Studies in states around the United States have validated Lance et al's first study in 1993 that found test scores higher in those schools with higher funding for school libraries and in schools where library media specialists took an active role in instruction (Lance, 1993).

\section{Methodology}

Fifteen schools were chosen for the study, three in each of five geographic areas of Los Angeles. Schools were eligible if their new Wonder of Reading library had been open for at least one year and had at least one administrator who was involved when the school applied for Wonder of Reading funding.

Six volunteer participants, involved before and after the new library opened, were recruited at each school-- the administrator, two teachers, two parents, and the library staff member. Eighty-one out of a possible 90 participants completed a 30-item survey/questionnaire. Eighty-six of the 90 participated in a brief interview. These procedures gathered perceptions about the overall impact of the programme and changes in 
nine specific domains, including the facility, student access to print, motivation, and library use.

Data from the California Department of Education and local district library annual reports were also gathered to identify and compare school characteristics, such as enrollment, number of low-income students, number of books and books per student. Academic Performance Index (API) scores for these schools were also compared from the inception of this composite of testing results in California from 1999 to 2002.

Responses to each question before and after The Wonder of Reading programme were tallied by participants' roles and put into tables showing raw totals and total percentages as well as percentages of responses by role. Responses before and after ranged over 5 choices, from strongly disagree, to disagree, to neutral, to agree, and strongly agree.

Typed notes from interviews were grouped by role so that responses could be seen together. Responses describing the overall impact were followed by perceptions about specific changes in nine areas related to the facility, student access to print, motivation, and library use. Recurring themes were highlighted and listed to gather data about patterns of response by role and by school characteristics.

\section{Findings}

School Characteristics: Schools sampled were taken from five geographic areas of the city. All were elementary schools with students in grades Kindergarten through five. Three were magnet schools on traditional 9-month calendars; 6 had enrollments over 1000 students on year-round calendars, and 6 were on traditional calendars.

Table 1: Largest ethnic group by number of schools

\begin{tabular}{lcc} 
Ethnicity & Schools $(\mathbf{n}=\mathbf{1 5})$ & Percentages \\
\hline Hispanics & 9 & 6() \\
African Americans & 3 & 20 \\
Caucasian & 2 & 13 \\
Asian & 1 & 7 \\
\hline Total & $\mathbf{1 5}$ & $\mathbf{1 0 0}$
\end{tabular}

The largest ethnic group of students served was Hispanic American (Table 1); three of the schools served predominantly African Americans; two were majority Caucasian; and one school had a majority Asian American population. 
Table 2: Students' Socio-Economic Status (SES)

\begin{tabular}{lccl}
$\begin{array}{l}\text { Students qualifying } \\
\text { for Free/Reduced } \\
\text { Lunch fee }\end{array}$ & Schools & $\%$ & Schools \\
\hline Over $80 \%$ & 9 & 60 & A, B, C, E, F, G, \\
& & & I, L, M \\
$50 \%-80 \%$ & 3 & 20 & J, K, O \\
Under $50 \%$ & 3 & 20 & D, H, N \\
\hline Total & $\mathbf{1 5}$ & $\mathbf{1 0 0}$ &
\end{tabular}

Thirteen out of fifteen schools, $87 \%$, served students where over $50 \%$ qualified for free or reduced lunches, an indicator that a majority of the students were from low-income families (Table 2).

Table 3: Change in average number of hooks per pupil

\begin{tabular}{lcc} 
Books per pupil & $\begin{array}{c}1999 \text { or } \\
\text { before }\end{array}$ & 2002 \\
\hline 9 or more per pupil & 0 & 9 \\
Less than 9 per pupil & 15 & 6 \\
Totals & 15 & 15 \\
& Schools $(n=15)$ &
\end{tabular}

Note. The district average was 9 books per pupil in spring 2002. 11.9 books per pupil were the reported state average in 2002. Year-round school figures reflect the number of books per pupils on campus.

Table 3 shows that all 15 schools had less than nine books per student. By spring, 2002, nine out of 15 schools had nine or more books per student. Eight out of the 15 schools increased their number of library books by over $100 \% ; 4$ of these increased by over $200 \%$ and 1 increased by over $300 \%$. The average number of books in these 15 school libraries in 1999 was 4,249 . By 2002 , the average number was 8,574 , an average $102 \%$ increase.

Increases in the number of books came from The Wonder of Reading's $\$ 10,000$ for books. Increased state funding from the California Public School Library Act of 1998 gave Los Angeles schools \$20 per pupil for books and library technology, the effects of which began to show beginning in 1999. In other cases, schools chose to supplement this funding with other categorical monies to build library collections.

Table 4 shows high test scores for students in relatively more affluent schools from the start, suggesting a relationship between higher socio-economic status (SES) and achievement. Schools serving the lowest-income students improved an average of 165 points. 
Table 4: Comparison of Percentage of Students With Free/Reduced Lunch and API Scores

\begin{tabular}{|c|c|c|c|}
\hline $\begin{array}{l}\text { Free lunch } \\
\text { Percentage }\end{array}$ & $\begin{array}{c}\text { No. Schools } \\
(n=15)\end{array}$ & $\begin{array}{c}1999 \\
\text { Average API }\end{array}$ & $\begin{array}{c}2002 \\
\text { Average API }\end{array}$ \\
\hline $55 \%$ or less & 4 & 820 & 870 \\
\hline $59-90 \%$ & 8 & 502 & 622.5 \\
\hline Over $90 \%$ & 3 & 445.3 & 610.33 \\
\hline
\end{tabular}

\section{Description of the school libraries before The Wonder of Reading}

No participant in these interviews had much positive to say about their old library. Words such as dark, crowded and cramped were used to describe them. One called it a dungeon. Another called the old library an appendage and a sick one at that. Many teachers interviewed reported having stopped using the old library, saying it was not worth it. While other schools were not so disparaging about the old library, they still reported that the small size meant that students had little freedom of movement, that only one class could fit at one time, and that the place appeared disorganised and uninviting.

Staffing was limited to a 3-hour aide. As one aide described it, this allowed only for damage control. The book collections were out of date and in poor condition, lacking, as one teacher put it, curb appeal. "First impressions make a difference," one teacher stated, the implication being that the old library did not make a good one. Another teacher said that students were interested in the library before but there was nothing there for them.

Access was limited to weekly or bi-weekly class visits. Teachers brought students in, rushed them to get a book, and hurricd them out. If a child forgot his previously checked-out book, he had to wait another two weeks, in some cases, to exchange it. The library was not open beyond the school day. Books, except in one instance, were not allowed to be taken home. Student motivation to read the old books was low.

Parents were not involved except, in one case, to keep the library open longer in the absence of full-time staff. The library was not able to support student learning related to curriculum nor did it meet their recreational or personal interests or needs.

What impact, then, did participants perceive following the implementation of The Wonder of Reading programme? Did pereeptions vary by roles? Did they vary by school characteristics?

\section{Overall Findings}

"We have a library." In several schools, the former library had been virtually nonexistent in the eyes of users. The Wonder of Reading library, then, was a notable change. Participants spoke about how much students love to visit the library and, that if teachers forgot their library time, students would remind them. They spoke about the feeling of selfesteem, that people felt better about being at the school. They said the library was a source of pride. One called the library a foundation from which to build the programme.

Principals, and often the assistant principals or programme coordinators, who worked with them, saw the library as a catalyst for turning the whole school around, changing school 
culture. Several in the study were termed "turn-around schools." In these schools, a new principal had engaged the whole school community in the application and fundraising effort. The library improvement effort, then, took on added significance. The project became for some a symbol of accomplishment and of where the school was headed. In a more pragmatic comment, one principal mentioned that the library helped with teacher recruitment. He mentioned its importance in providing access for all in a community where there are few books in the homes.

Parents commented on the library facility's spaciousness and its welcoming atmosphere. They appreciated having so many new books and noted the excitement that their children expressed about using it. The first comment from one parent was, "Oh gosh, it makes us so proud." She called it the centerpiece of the school, special. Another said that they were excited about the plans for the new library but didn't know that the change would be so extensive. One called the library "A real Wow! Very different, more relaxed, comfortable, with spaces, books, and computers right here."

The library staff participants consisted of 3 library media teachers (LMTs) and 12 library aides. One LMT commented on the physical appearance of the library as "the most beautiful place in the school" in an area where beauty was not often seen. "It attracts people. People want to be in a beautiful place, a welcoming place for students and staff. It is a place that attracts." He commented that circulation had increased dramatically.

One LMT in a large, over-crowded, year-round school called the library a "haven." In another low-income school, the library aide described how she keeps the library open late for latchkey children and for homework tutoring, providing a nurturing place for them. Participants commented that the library atmosphere was more relaxed than that of the hectic classroom.

One library aide in a gifted magnet school commented that "there is a joy about books here." She pointed out that some of the students were reading on a high-school level, creating a broad spectrum of collection needs. She commented that at first students were just excited. Now she sees students selecting more quality books. This appeared partly due to the efforts of the library aide herself who was reading the books and actively recommending them to students.

This aide's parting comment was that she could stand on her head all day and it would not make any difference. "It is the leadership here than makes the difference. It is because the principal has reading as her focus that we all do and so the kids do too." This principal's passion was confirmed in her statement, as follows: "At the centre is the book. We don't do any froo-froo stuff. Reading is the point. We model it, talk about it, and celebrate it. We want reading for the sake of reading. At the heart, you have to have access to books. The library alone won't do it. Kids need support." Another actively involved Assistant Principal noted about the new library, "It is central to everything we do here. I can't imagine a school not having a vital, functioning library. Everything we do here is about literacy. The library media center is the place where people go to make those connections."

\section{Summary of Findings}

Wonder of Reading libraries led to a cascade of changes impacting student and school community access and use. Changes in the school library appear to have expanded not only 
the facility but student access to print in both physical and affective dimensions. Changes in this segment of the school appeared to affect attitudes that, in turn, influenced practices. Hours expanded, a requirement in the application. Students could exchange books at any time during the day. In most schools, students could check out multiple books, a change from the one-student-one-book practice common in the school district. Books went home, another change for some schools. One principal noted that the loss rate was minimal because the school stressed responsibility but also because the students had developed a respect for the library and the resources there. Thus, the study confirmed changes in student library use and investment in the programme, a liberalisation of use policies, and a change in school culture regarding books, reading, and libraries.

Student access to print, opportunities that urban students may not otherwise have, was expanded in many ways:

- The number of books increased.

- The space to house the additional books increased.

- The space to house potential users increased.

- Staffing and hours increased in many cases.

- Policies allowing multiple books to go home became the norm.

- Adults became available for modeling and guidance.

- The visual appeal of the space invited readers in.

- A warm, welcoming atmosphere encouraged them to stay.

- Books and other resources offered "curb appeal", encouraging student use.

- The space offered urban students quiet and comfort conducive to engaging in print.

Student use was expanded:

- Book circulation increased.

- The space could accommodate overlapping uses by classes, small groups, and individuals.

- Students were able to come on their own before, during, and after class.

- Teachers made assignments because the resources for students were now there.

- Students found resources for independent, self-selected reading.

- Students in some schools were able to use technology in the library.

- Students were involved in special literacy events.

- Where there was an LMT, students began to engage in research related to curricular themes.

\section{Variations in Response by Role}

In interviews, teachers expressed gratitude for simply having a functional library. They commented on the importance of "curb appeal" in enticing students to read. They 
described how well the new library complemented their work with children in the classroom, enabling them to make assignments previously withheld due to lack of resources.

Parents appreciated the beauty of the space. They observed that their children were excited about going to the library and were reading more. They appreciated having the resources right there at the school rather than having to purchase books or to take their children to the public library, which, in 7 school communities, had been closed.

Comments by the library staff reflected their service orientation to students. The 12 library aides commented on the increased activity and the workload, which they gladly took on. The three library media teachers expressed some frustration due to pending funding cuts that were either threatening or eliminating their positions. They described their instructional collaborations with teachers initiated to engage students in reading and in research.

Administrators had the broadest view. Their philosophies were reflected in the attitudes and activities of the students and staff. One principal of a magnet school in an urban area noted the importance of the library in setting a tone and providing the resources for academic learning. Another reflected that. "The library saved me," recalling her own immigrant roots and the positive role that The Boxcar Children had on her as a young reader. Principals noted that the new library served as a symbol of how much the school cared for students and what the school community could accomplish together. One commented and others implied that the new library had changed school culture with regard to reading, making reading a desirable way to spend time.

\section{Variation in Response by School Characteristics}

Responses from schools with many low-income students, the majority, showed that parents saw the library as a source of empowerment for their children. The space was the most beautiful place in the school. Parents were grateful to have a safe learning place for their children. Safety was an important issue for these parents. They felt that the library kindled desire for learning in their children in a way not possible before. One parent whose comments were translated from Spanish said about the library's role, "It plays a very important role fundamental for the education of children. If there were no library, how could you improve the reading abilities of children? It is critical to education."

In higher-income areas, parents were also grateful not to have to buy so many books for children whose interests were constantly changing. They pointed to the value of the library in convincing potential business partners to provide additional support. At one school, parents had tried to convince local businesses to contribute to the school with little success. After the opening of The Wonder of Reading library, the response turned to asking how they could help. Parents from relatively more affluent areas spoke of the library as a tool for marketing the value of public education to families considering private school. Principals used the new library to recruit new teachers as well as to foster partnerships with community groups.

\section{Student Achievement and Expenditures on the Library Programme}

The 15 schools in this study all invested heavily in their school libraries. Each one raised from $\$ 25,000-\$ 40,000$ in matching funds. Eight schools increased their book 
collections by over $100 \%, 4$ by over $200 \%$. Three of the schools found funding from grants or a combination of accounts to hire a full-time LMT in addition to the 6-hour library aide. One small school without special categorical funding still managed to hire a part-time T.A. with a Masters Degree in Library Science to work with their library aide. Another hired a second full-time library aide.

\section{Table 5: Ranked API Growth and Investment in School Libraries}

\begin{tabular}{|c|c|c|}
\hline Schools & $\begin{array}{c}\text { API Growth 1999- } \\
\mathbf{2 0 0 2}\end{array}$ & $\begin{array}{c}\text { Number of books } \\
\text { Percentage of } \\
\text { increase }\end{array}$ \\
\hline C & 13 & 20 \\
\hline H & $26^{*}$ & 50 \\
\hline N & $29^{*}$ & 129 \\
\hline D & $65^{*}$ & 28 \\
\hline O & $78^{*}$ & 184 \\
\hline A & $86^{*}$ & 60 \\
\hline B & 127 & 31 \\
\hline I & 127 & 108 \\
\hline M & 129 & 383 \\
\hline J & 140 & 42 \\
\hline G & 156 & $24+$ LMT \\
\hline F & 159 & 212 \\
\hline L & 164 & $279+$ LMT \\
\hline E & 166 & $212+$ LMT \\
\hline * Schools with baseline API scores at 638 or above and $59 \%$ or fewer \\
\hline students qualifying for fres lunch & \\
\hline
\end{tabular}

Did this investment in school libraries lead to improved student achievement? Fourteen out of 15 schools raised their Academic Performance Index (API) test scores by over 100 points. Seven of these schools increased their number of books by over $100 \%$ and/or had hired a library media teacher along with the District-funded library aide.

The five schools with the fewest students qualifying for free lunch already had high baseline scores. One school where the API increase was modest also appeared to have made the smallest investment in the collection, increasing the number of books by $20 \%$ from 1999 2002. This school's use policies and practices had also not changed to the degree seen in other schools. For example, students could not come to the library on their own time.

Investment in the library and the concurrent changes in library use appeared to be reflected in API scores. Between 1999 and 2002, these schools' scores ranged from increases of 127 tol91 points. It appears that, as studies by Lance, et al, suggest, investing in school libraries has a positive impact on student achievement (Lance, Welborn, \& Hamilton-Pennell, 1993).

\section{Conclusion}

The findings of this study affirm findings in previous studies that providing plentiful access to interesting reading materials fosters engagement and increased time spent reading 
(Kirsch, et al, 2003; Krashen, 1993; McQuillan, 1998). This increased time may, in turn, make a difference to reading growth.

The results suggest that investment in the school library pays achievement dividends. (Baughman, 2000; Lance, Welborn, and Hamilton Pennell.1993; Lance, Hamilton-Pennell and Rodney,1999; Lance, Rodney and Hamilton-Pennell, 2000; Lance, Rodney and Hamilton-Pennell, 2001). They show that access to print for low-income urban students is severely limited and that access through the school library can make an important difference to these young learners. The results further suggest that enlarging and re-stocking the school library may serve as the first in a cascade of changes that positively affect student engagement in reading.

Although The Wonder of Reading could not claim credit for all of the changes that occurred, the programme appeared to be well timed, building upon a convergence of funding and attention to reading that may have made the changes brought about by the programme even more effective. The findings suggest that offering students an enlarged and re-designed space with shelves well-stocked with new books can become a symbol that communicates every day to students how much the adults around them value them and their success as readers.

\section{Next Steps}

On-going funding for school libraries will be vital for these schools to continue to grow these programmes and to nurture more schools to apply for the programme. Once a critical mass of school libraries have been remodeled, it may appear unacceptable for any school in the District to continue to offer a library facility and collection that do not meet this standard. The most obvious need, however, is to hire library media teachers to, colloquially, put a cook in the kitchen. This funding will need to be from a stable, consistent source rather than from grant funding or other sources that terminate before the programmes can mature.

Additional research is needed to gather more empirical data, such as comparing schools with similar characteristics with and without Wonder of Reading libraries. Case studies of student use before and after programme implementation or between schools with and without the programme could yield useful data. Exploring the impact of adding a library media teacher in these schools is clearly needed, as is the effects of adult volunteers working one-on-one with students.

\section{References}

Baughman, J.C. (2000). School libraries and MCAS Scores. Unpublished paper presented at a symposium sponsored by the Graduate School of Library and Information Science. Simmons College. from http:/artemis.simmons, cdu/baughman/meas-school-librarics/.

Cullinan, B.E. (2002). Independent reading and school achievement. School Library Media Qutarter/. 13. 123, from http:/www.ala.org/alsis/SLMR voll3 independent/independent_main.html

Duke, N. (2000a). Print environments and experiences offered to first-grade students in very low-and very high-SES school districts. American Ederational Research Association Joninal, 37(2), 441-78.

Duke, N. (2000b). 3.6 minutes per day: The scarcity of informational texts in first grade. Reading Reserech Quctr/crly, 35, 202-224.

Elley, W., \& Mangubhai, F. (1983). The impact of reading on second language learning. Recuding Reserurch Quatrerly, 19(1), 53-67. 
(iambrell. L. (1996). Creating classroom culures that foster reading motivation. The Rededing Tere her. 50(1). $1+-25$.

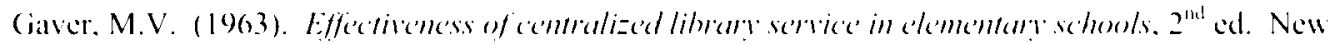
Brunswick. NJ: Rutgers University Press.

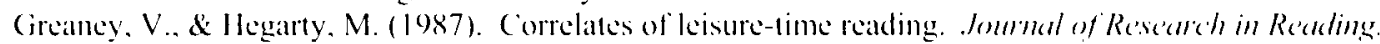
I0(February). 3-20.

(iuice, S., Allington, R., Johnston, P., Baker, K., \& Michelson, N. (1996). Access?: Books, children, and literature-based curriculum in schools. The Vow deforette. 9. 197-207.

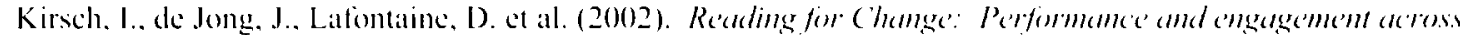

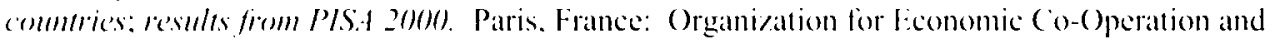
Development. from whw ocedorg.

Koskinen, P., Baker. T., Blum, I., Bisson, S., Philips, S., \& (reamer. T. (2000). Book alcesess, shared reading. and audio models: the effects of supporting the literacy learning of linguistically diverse students in school and at home. Jonrmal of Edencational Psichologe: 92 (1), 23-36,

Kratshen. S. (1993). The poner of reading. Englewood, ( (): Libraries Unlimited.

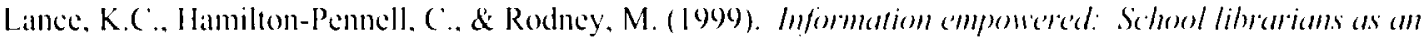

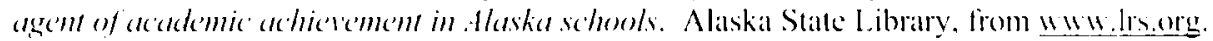

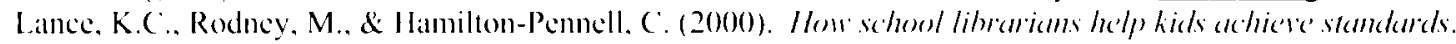
San lose: Ili Willow, from www. Irs.org.

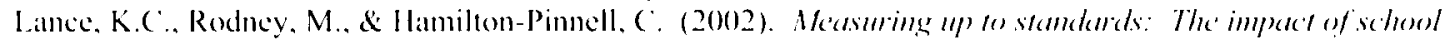

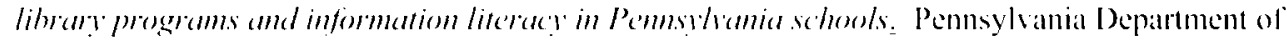
liducation. from www. Irs.org.

Lance, K.C.. Welbom, L., \& Hamilton-Pennell, C. (1993). The imperet of school lihreny media centers on

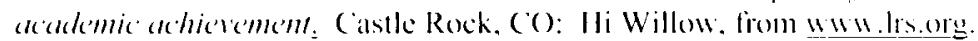

MeQuillan. J. (1998). The /iteract crisis: False claims and real solutions. Pontsmouth, NH: Ileinemann.

McQuillan, J.. L.eMoine, N., Brandlin, L., \& $0^{\circ}$ Brian. B. (1997). The (print-) rich get richer: library aceess in low-and high-achieving elementary schools. The (allifornio Reader. 30)(2), 23-25.

Morrow, L.M.. \& Weinstein, (.S. (1986). Encouraging voluntary reading: The impact of a literature program

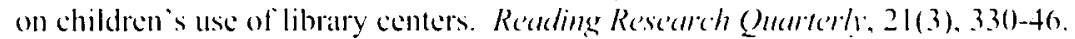

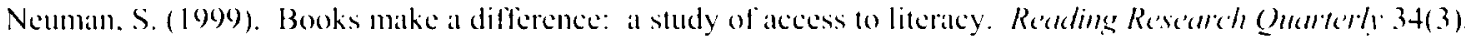
$2 \times 6-311$.

Neuman. S.. \& (elano. D. (200)1). Aceess to print in low-income and middle-income communities: an

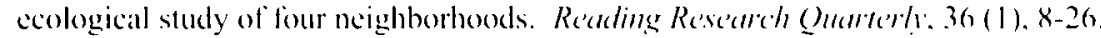

Romatowski. J.A.. Trepanier-Street. M.L.. \& Peterson. J. (1993). Saturday reading club: $\Lambda$ literature-based project in an urban school setting. Reeding Research and hnstrution, 33(2), 135-43.

Smith. (.. Constantino. R.. \& Krashen, S. (1997). Differences in print environment for children in Beverly Hills, compton and Watts. Eme'gency Libraricm, $24(4), 8-10$.

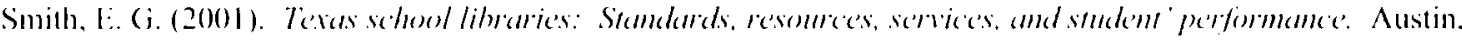

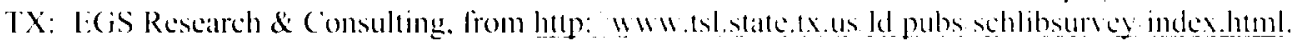

Taylor. B.M.. Frye. B.J. \& Maruyana. (i.M. (1990). Time spent reading and reading growth. flmoricam Eaducational Research Jominal, 27(2), 351-62.

Turner, J. (1995). The influence of classroom contexts on young children 's motivation for literacy. Re'uding Rescench (harrer/l, 30(3), $410-4+1$.

Worthy, J. (1996). Removing barriers to voluntary reading for reluctant readers: The role of school and classiroom libraries. lomguage Ar\%. 73, 48,3-492.

\section{Author Note}

Dr. Marilyn Nottingham Robertson has served the 700,000 students of the Los Angeles Unified School District (LAUSD) for 32 years, most recently as District Library Program Manager overseeing new school libraries, elementary programmes and library automation. She earned her B.A. from Occidental College and her M.A. and Ed.D. from the University of Southern California (USC), served as President of the California School Library Association (CSLA), and contributed language on the role of the school library programme to the California Department of Education's Reading/Language Arts Framework 